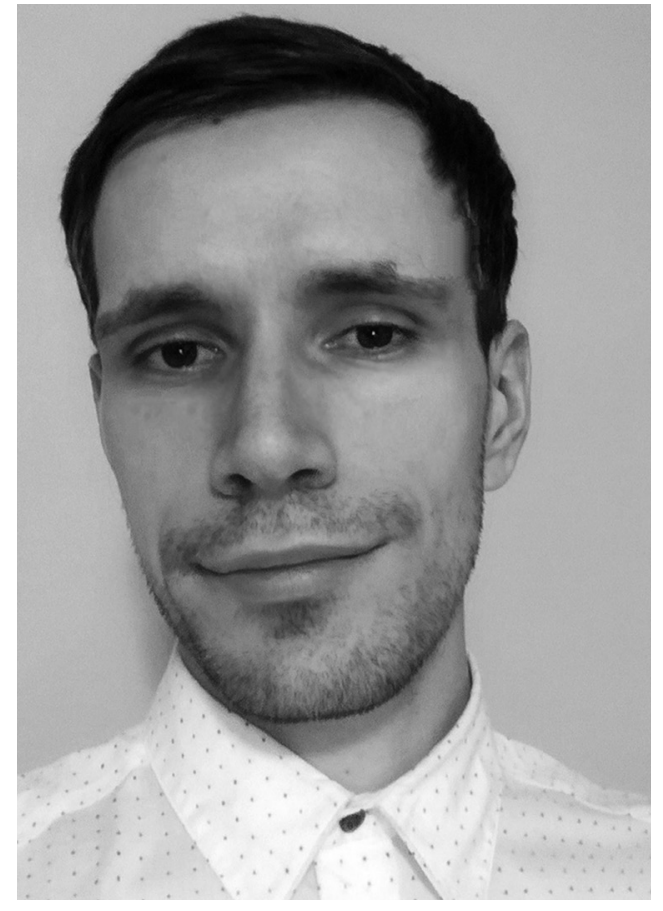

УДК: 316.77; 316.74:001

DOI: https://doi.org/10.32689/2617-

2224-2020-1(21)-324-335

\section{Черних Геннадій Андрійович,}

кандидат соціологічних наук, асистент кафедри галузевої соціології факультету соціології Київського національного університету імені Тараса Шевченка; 03680, м. Київ, просп. Глушкова, 4-д, тел.: +38 (068) 19964 85, e-mail: chernykh@ knu.иа

ORCID: 0000-0001-8440-0711

\section{Черных Геннадий Андреевич,}

кандидат сочиологических наук, ассистент кафедры отраслевой социологии факультета сочиологии Киевского наиионального университета имени Тараса Шевченко, 03680, г. Киев, ул. Глушкова, 4-д, тел.: +380 (68) 19964 85, e-mail: chernykh@knu.ua

ORCID: 0000-0001-8440-0711

Chernykh Gennady Andreevich,

Candidate of Sociology, Assistant Professor, Department of Sector Sociology, Faculty of Sociology, Taras Shevchenko National University of Kyiz, 03680, Kyiv, prosp. Glushkova, 4-d, tel.: +38 (068) 19964 85, e-mail: chernykh@knu.ua

\title{
ДОСЛІДНИЦЬКІ ТРАДИЦІї КОГНІТИВНОї СОЦІОЛОГІї ТА СОЦІОЛІНГВІСТИКИ - МОВА ТА ЗНАЧЕННЯ У СОЦІАЛЬНІЙ ВЗАЄМОДії
}

Анотація. Розглянуто специфіку розвитку дослідницьких традицій когнітивної лінгвістики та соціолінгвістики. Визначено проблеми розуміння буденної мови на сучасному етапі розвитку науки. Проаналізовано сучасний стан розвитку етнометодологічного підходу, ролі невербальних комунікацій у повсякденному спілкуванні. Обгрунтовано природу соціальної дії, особливості функціонування та взаємодії соціальних акторів за допомогою символів і значень. Розглянуто моделі комунікаційної взаємодії У. Шрама, Д. Маккуейла, Дж. Груніга, Т. Ханта, Ю. Габермаса, Н. Лумана. Розкрито зміст одного з ключових понять соціолінгвістики - 
“мовна ситуація”, яке визначається як сукупність форм існування мови (мов, регіональних койне, територіальних і соціальних діалектів). Особливу увагу приділено в сучасній соціолінгвістиці питанню про зв’язок і взаємодію мови і культури. Також розглянуто особливості розвитку когнітивної лінгвістики як мовознавчого напряму щодо функціонування мови як різновиду когнітивної, тобто пізнавальної, діяльності, а когнітивні механізми та структури людської свідомості - через мовні явища. Доведено основну гіпотезу когнітивної науки, що мисленнєві процеси можна трактувати як процеси оброблення та перетворення ментальних репрезентацій. Наведено ідеї головного прихильника та представника когнітивної соціологї - американського соціолога Аарона Сікурела. Також обгрунтовується зміст праць французького соціолога Ж. Подьоло та концепції соціолінгвістики А. Мейє, Ф. Боаса, Е. Сепіра, В. Матезиуса, Б. Гавранека, Й. Вахека та ін., які зробили значний внесок у виявлення ролі соціальних чинників у розвитку мови та продемонстрували зв’язок мови із соціальними процесами, а також соціальну роль літературної мови.

Ключові слова: мова, соціальна взаємодія, когнітивна соціологія, соціолінгвістика, комунікація, соціальні дії, символи, значення, мовна ситуація.

\section{ИССЛЕДОВАТЕЛЬСКИЕ ТРАДИЦИИ КОГНИТИВНОЙ СОЦИОЛОГИИ И СОЦИОЛИНГВИСТИКИ - ЯЗЫК И ЗНАЧЕНИЕ В СОЦИАЛЬНОМ ВЗАИМОДЕЙСТВИИ}

Аннотация. Рассмотрена специфика развития исследовательских традиций когнитивной лингвистики и социолингвистики. Обозначены проблемы понимания обыденного языка на современном этапе развития науки. Анализируется современное состояние этнометодологического подхода, роли невербальных коммуникаций в повседневном общении. Обоснованы природа социального действия, особенности функционирования и взаимодействия социальных акторов с помощью символов и значений. Автор анализирует разработаные модели коммуникационного взаимодействия В. Шрама, Д. Маккуейла, Дж. Грунига, Т. Ханта, Ю. Хабермаса, Н. Лумана. Раскрыто содержание одного из ключевых понятий социолингвистики - “языковая ситуация”, которое определяется как совокупность форм существования языка (языков, региональных койне, территориальных и социальных диалектов). Особое внимание в современной социолингвистике уделается вопросу о связи и взаимодействии языка с культурой. Также рассмотрены особенности развития когнитивной лингвистики как языковедческого направления, которое рассматривает функционирование языка как разновидность когнитивного, то есть познавательной деятельности, а когнитивные механизмы и структура человеческого сознания - через языковые явления. Подтверждается основная гипотеза когнитивной науки, что мыслительные процессы можно трактовать как процессы обработки и превращения ментальных репрезентаций. Приводятся идеи главного сторонника и пред- 
ставителя когнитивной социологии - американского социолога Аарона Сикурела. Также обосновано содержание работ французского социолога Ж. Подьоло и концепции социолингвистики А. Мейе, Ф. Боаса, Э. Сепира, В. Матезиуса, Б. Гавранека, И. Вахека и других, которые внесли существенный вклад в выявление роли социальных факторов в развитии языка, продемонстрировали связь языка с социальными процессами и социальную роль литературного языка.

Ключевые слова: язык, социальное взаимодействие, когнитивная социология, социолингвистика, коммуникация, социальные действия, символы, значение, языковая ситуация.

\section{RESEARCH TRADITIONS IN COGNITIVE SOCIOLOGY AND SOCIOLINGUISTICS - LANGUAGE AND MEANING IN SOCIAL INTERACTION}

Abstract. The specificity of the development of the research traditions of the cognitive linguistics and sociolinguistics is considered in the article. The problems of understanding everyday language at the present stage of the science development are substantiated. The current state of the development of the ethnomethodological approach, the role of non-verbal communications in everyday communication is analyzed. The author substantiates the nature of the social action, peculiarities of functioning and interaction of the social actors through symbols and meanings. The author analyzes the developed models of the communication interaction by W. Schramm, D. McQuail, J. Grunig, T. Hunt, Y. Habermas, N. Luman. The content of one of the key concepts of the sociolinguistics - "linguistic situation”, which is defined as a set of forms of existence of the language (languages, regional koine, territorial and social dialects) is revealed. The author notes that special attention is paid in the contemporary sociolinguistics to the question of the connection and interaction of the language and culture. The features of the development of the cognitive linguistics as a linguistic trend, which considers the functioning of the language as a kind of cognitive, that is, knowing, activity, and examines the cognitive mechanisms and structures of the human consciousness through linguistic phenomena. The author confirms the basic hypothesis of the cognitive science that the thinking processes can be interpreted as processes of processing and transformation of the mental representations. The author draws on the ideas of the main proponent and representative of the cognitive sociology - American sociologist Aaron Cicourel. Also - substantiates the content of the works of the French sociologist J. Padioleau and the concepts of sociolinguistics A. Meiller, F. Boas, E. Sapir, V. Mathesius, B. Gavranek, J. Vachek and others, who made a significant contribution to the identification of the role of the social factors in the development of the languages and demonstrated the link between the language and the social processes and the social role of the literary language.

Keywords: language, social interaction, cognitive sociology, sociolinguistics, communication, social actions, symbols, meaning, linguistic situation. 
Постановка проблеми. У цьому дослідженні аналізується проблема розвитку таких важливих наукових напрямків дослідження мови:

1. Формування та розвиток повсякденних комунікативних практик в структурі сучасних культурних трансформацій;

2. Детермінація мовної ситуації та процесів взаємодії мови та культури;

3. Інтерпретація механізмів когнітивного переосмислення мови через соціолінгвістичний аналіз та когнітивну соціологію.

На сучасному етапі наукового пізнання мови - як невід'ємної ланки культурного розвитку людей, науковці ще не дійшли до консенсусу дослідження мови в загальній теорії. Все це виражається в плюралізмі думок, уявлень та детермінацій дефініцій в сучасному мультипарадигмальному просторі науки. Особливості культурного різноманіття, національних підходів та шкіл, які пов’язані 3 дослідженнями мови - створюють засади безкінечного аналізу та емпіричного переосмислення даного явища. Що в свою чергу ускладнює сам процес дослідження, відображення та розуміння соціокультурних змін, які відбуваються в повсякденних комунікативних практиках. Так, наприклад, на даному етапі розвитку когнітивної соціології та соціолінгвістики, змістився дослідницький акцент, ніж на початку зародження цих наукових напрямків дослідження мови. Адже колосальні зміни, які відбулися за 100 років соціального розвитку та наукового становлення - формують зовсім інші детермінанти смислів та значень даного об'єкт-предметного дослідження.
На нашу думку, постмодерний світ відрізняється від світу модерну тим, що модерн - це світ, до якого має прийти все людство, а постмодерн це світ, в якому людство може перейти на нову віху соціального розвитку. Тому - для дослідників соціального світу постає завдання спрогнозувати можливості формування світу модерну для всього людства та особливості розвитку постмодерної реальності.

Спираючись на засади модерного дослідження мови, сучасні постмодерні тенденції розвитку розширюються інтерпретаціями смислів та значень. Конструюються нові соціальні та теоретичні конструкти, які не завжди стають частиною наукового обігу та соціальної реальності, й лише з плином часу відбувається їх інституціоналізація в науці та житті.

Аналіз останніх досліджень i публікацій. Основи соціологічних досліджень в СРСР були закладені в 20-30-х pp. XX ст., працями радянських вчених Л. П. Якубинского, В. В. Виноградова, Б. А. Ларіна, В. М. Жирмунський, Г. А. Шор, М. В. Сергіївського, Е. Д. Поліванова, які вивчали мову як суспільне явище на основі марксистського розуміння мови як суспільного явища та історико-матеріалістичних принципів аналізу суспільних відносин. Засадничі ідеї для сучасної соціолінгвістики підготували також праці представників соціологічного напрямку у французькому мовознавстві (А. Мейе), який вніс істотний внесок у виявлення ролі соціальних чинників у розвитку мови; роботи американських етнолінгвістів, що розвивали ідеї Ф. Боаса і Е. Сепіра в зв'язку мовних і соціокультурних систем; праці 
представників Празької лінгвістичної школи - В. Матезиуса, Б. Гавранека, I. Вахека, що продемонстрували зв'язок мови з соціальними процесами і соціальну роль літературної мови; дослідження німецьких вчених, особливо Т. Фрінгса і створеної ним лейпцігської школи, яка обгрунтувала соціально-історичний підхід до мови і необхідність включення соціального аспекту в діалектологію; оригінальні роботи в галузі мовної ситуації і культури мовлення японської школи “мовного існування".

У 60-70-х рр. інтерес до соціологічних проблем мови зріс у зв'язку, з одного боку, з потребами сучасного суспільства, для якого проблеми мовної політики та інші практичні аспекти соціолінгвістики набувають все більшої актуальності, i, з іншого - з критикою структурної лінгвістики, з прагненням подолати обмеженість іманентно підходу до мови і глибше проникнути в природу мови як суспільного явища.

Соціолінгвістичні напрями, що розробляються вченими різних країн, характеризуються різною методологічною орієнтацією. Деякі напрямки зарубіжної соціолінгвістики (наприклад, в США) орієнтуються на біхевіористську модель мовної поведінки, символіко-інтеракціоністську теорію соціальної взаємодії, феноменологічну соціологію. Соціолінгвістика, що розроблялася в СРСР і деяких інших країнах, спиралася передусім на історичний матеріалізм і на приватні теорії марксистської соціології - теорію соціальної структури суспільства, теорію соціальних систем, соціологію особистості та ін.
Однак, слід зазначити, що соціологія розглядає спілкування як соціально обумовлений вид діяльності людей. Психологія досліджує процес встановлення і розвитку контактів між людьми з метою обміну інформацією. Лінгвісти процес спілкування представляють як актуалізацію комунікативної функції мови в тих чи інших мовних ситуаціях. Головним елементом мовної комунікації є механізм, за допомогою якого здійснюється переведення процесу передачі і сприйняття інформації в соціально значущий результат персонального і масового впливу. У соціолінгвістичному аспекті необхідно вивчати перш за все особливості функціонування мови в умовах масової соціальної комунікації.

Тут на перший план, для нашого дослідження, виходить поняття “мовної ситуації”, яке нами інтерпретується як сукупність форм існування мови (мов, регіональних койне, територіальних і соціальних діалектів). Що в свою чергу - визначає різні методологічні підходи до вивчення мови та значень в соціальній взаємодії. Зі зміною мовної ситуації - змінюється культура, що в свою чергу змінює саму мову та значення. 3 глобалізаційним розвитком створюються нові умови для розвитку мови. Відбувається все більше запозичень в руслі інформаційного культурного розповсюдження, так званих механізмів шерінгу (від англ. share - ділитися) та фідбеку (від англ. feedback - відгук), що відіграє важливе значення в сучасному культурно-інформаційному просторі. Все частіше відбувається культурна дифузія - просторове розповсюдження культурних 
досягнень одних суспільств у інші. 3 розвитком культурної динаміки відбувається розвиток модерного світу, й інтенсивність цієї динаміки в сучасному світі - вражає своїми масштабами. Інформаційних вибух - швидке збільшення кількості публікацій або об'єму даних і ефект, який виникає як наслідок - став рушійною силою культури інтелектуалів сучасного світу. За п'ять попередніх років людством було вироблено інформації більше, ніж за всю попередню історію. Що на нашу думку - значно ускладнюе можливості критичного дослідження мови та значень у соціальній взаємодії - на сучасному етапі наукового розвитку.

Сучасний напрям дослідження мови та комунікації базується на різних підходах, Ф. В. Шарков виділяє кілька підходів [1]. Перший методологічний підхід базується на класичній позитивістської методології суб'єктно-об'єктних диспозицій. Він представлений концепціями структурного функціоналізму, системного підходу, інформаційного суспільства, технологічного детермінізму, комп'ютерної футурології та ін. Онтологія соціальних комунікацій в даному підході грунтується на системних зв’язках і функціях. Комунікативні технології ставлять завдання сконструювати бажаний образ суб'єкта і певні соціальні зв'язки в системі. Цей підхід можна порівняти з принципом класичної кібернетики, який передбачає жорсткий контроль за поведінкою системи, при якому виключаються всі непотрібні взаємозв'язки [1].

Очевидно, що різноманітні моделі комунікації конструюються за функціями, змістом, формою, цілями і за- вданнями. Практичне застосування на сьогоднішній день в інтегративних системах знаходять наступні моделі комунікації:

1. Авторитарна модель - описана У. Шраммом і Д. Маккуейлом грунтується на максимальному обмеженні свободи інформації і жорсткому адміністративно-управлінському контролі за діяльністю ЗМІ [2, с. 148].

2. Двостороння асиметрична модель - одна з чотирьох моделей, запропонованих Дж. Грунігом і Т. Хантом, що виникла в 20-х роках ХХ ст. в неї включається зворотний зв’язок, при якому зберігається влада комунікатора над комунікацією, що і створює певну асиметрію [3].

3. Двостороння симетрична модель - виникла у 60-70-х рр. ХХ ст., описано Дж. Грунігом і Т. Хантом[3], в ній зазначається, що симетрія досягається збалансованістю відносин між одержувачем і відправником повідомлення.

4. Некласична методологія грунтується на когнітивній моделі суб'єктно-об'єктних відносин з приводу об'єкта. Автор цієї методологіi, німецький філософ Ю. Габермас віддає перевагу позитивній науці у вивченні соціальних суб'єктів. Інструментом реалізації практичних інтересів людей він розглядає міжособистісні “інтеракціï” (комунікації) як спосіб емансипації, вивільнення від різного роду впливу (політика, економіка тощо) і примусу. Ю. Габермас відрізняє “справжні” комунікації від “помилкових" комунікацій, намагається обгрунтувати “технічну раціональність” перенесення технічних засобів і методів на міжособистісні комунікації [4, с. 115]. 
5. Постнекласичний підхід грунтується на працях Н. Лумана, зводить природу соціального до суб'єкт-суб'єктних відносин, виключаючи об'єктність. Суспільство розглядається як мережа комунікацій, а комунікації мають можливість до самоопису суспільства і його самовідтворення (принципи самореферентності і аутопойезіса Н. Лумана). Комунікація в даному випадку постає як активне самоорганізоване середовище, де найпростіші соціально-комунікативні системи формуються через взаємне узгодження дій i переживань присутніх учасників спілкування. Суспільство охоплює всі дії, досяжні для зіставлення один з одним в комунікації. Дія розуміється як справжній елемент соціальної системи, який виробляється і сприймається в ній у співвіднесенні (комунікації) з іншими діями-подіями [5].

Однак, як ми вже зауважили, в соціологічному дискурсі аналізу мови та комунікаційної взаємодії існує традиція плюрального безкінечного світу моделей: починаючи з моделі Аристотеля ("Оратор - Промова Аудиторія”) та закінчуючи теорією засобів комунікації М. Маклюена. Всі ці моделі відносно можна звести до аналізу макро та мікрорівнів. Макрорівневих моделей (теорій) комунікації набагато менше ніж мікрорівневого аналізу. Що говорить про складність фундаментального відображення комунікації в соціальних системах на глобальному рівні - в їх традиційному розумінні.

Формулювання цілей (мети) статті. Отже, виходячи зі змістовного аналізу вищезазначених теоретичних засад, мета даної статті полягає у змістовній систематизації проблем наявних у структурі розуміння когнітивної соціології та соціолінгвістики. Та аналіз відображення в науковому дискурсі традиційних суперечностей дослідження мови та значення у соціальній взаємодії.

Для вирішення поставленої мети, нами було поставлено за ціль - проаналізувати ідеї когнітивної соціології американського соціолога А. Сікурела, Ж. Падьоло та традиційні підходи соціолінгвістичного напряму дослідження. Спираючись на аналіз робіт А. Сікурела - нами було встановлено:

1. Існують три етапи конструювання людьми (суб'єктами) соціальної дійсності. Перший - це суб'єктивна організація та класифікація “емпірики” (досвіду) в простих (елементарних) актах “говоріння”, другий - прояв “теоретичних понять”, третій етап пов’язаний із суб'єктивним аналізом розмови або тексту.

2. Головними для когнітивної соціології є такі поняття:

- методи інтерпретації, “мають на меті пов’язати ідеї феноменологів і етнометодологіï і співвіднести їх з роботами, що стосуються використання мови, пам'яті та уваги, або взагалі з усім тим, що відноситься до області обробки інформації (information processing)";

- інтеракційна компетентність, “що дозволяє уточнити відносини між когнітивними процесами, появою контекстів і наративними словниками (accounting vocabularies)”.

3. А. Сікурел в цілому залишився далеким від подолання інтеракціоністського підходу і встановлення нових форм зв’язку з макросоціаль- 
ними аспектами реальності. Що відображає загальну традицію - наведену нами раніше.

4. Соціологічний аналіз поширюється також і на поле невербальної комунікації (через вивчення мови глухих), що не зводиться до моделі вербальної комунікації. А. Сікурел виявляє ту обставину, що актори і дослідники в своїй пізнавальній діяльності змушені спиратися на загальні методи інтерпретації. Дослідник “може зробити свої спостереження об’єктивними тільки в тому випадку, якщо він пояснить особливості методів інтерпретації і свою залежність від них, тобто, якщо його дослідницька діяльність буде повноцінною”. Отже, прагнення до наукової об’єктивності в області соціальних наук має на увазі потребу у соціологічній рефлективності. Нарешті, тут поставлено питання про зв'язок з макросоціальних аспектами, оскільки мова йде про те, щоб “експлікувати роль знання і контексту в вивченні соціальної структури”. Зокрема, через процедури “набуття соціальної структури” в ході соціалізації [6, с. 36-38].

5. На думку А. Сікурела, “представники мікросоціології не можуть обмежуватися вивченням соціальної взаємодії як локального і самодостатнього продукту, точно так само як теоретики макросоціології не можуть залишати поза увагою мікропроцеси" [7].

В середині 80-х років у Франції можна було спостерігати підвищений інтерес до когнітивного виміру соціальної дії. У зв’язку з цим серед інших можна назвати роботи Жана Падьоло або Бернара Конена, які, втім, піднімають питання, харак- терні скоріше для когнітивних наук (що включають в себе, зокрема, біологічні, психологічні, лінгвістичні науки, а також науки про штучний інтелект). Але, беручи до уваги характер діалогу, який Жан Падьоло та Бернар Конен ведуть 3 когнітивними науками, можна поставити запитання, чи не ризикуємо ми, коли, наприклад, намагаємося встановити точки дотику з етологією, впасти в натуралізм, який намагається вибудувати соціальні науки за образом наук натуралістичних? Це питання залишається відкритим для подальшого дослідження.

Французьский соціолог Ж. Подьоло намагався за допомогою когнітивного підходу вирішити одну 3 найскладніших соціальних проблем - проблему соціального порядку. На його думку, природа соціальної дії є когнітивною, а соціальний актор являє собою “людину соціологічну, когнітивну”, яка створює свої соціальні уявлення за допомогою символів і значень. Під символом він розуміє те, що “представляє іншу річ: символ займає місце іншого предмета, заміщає його або викликає згадку про нього в пам'яті” [8].

Колективна взаємозалежність дій людей, на думку Подьоло, зумовлена взаємними очікуваннями. Колективні дії передбачають згоду партнерів 3 приводу правил прийняття рішень. Однак, з когнітивної точки зору, консенсус не зводиться до простої угоди між індивідами. Він виникає при узгодженні взаємного сприйняття соціальними акторами по відношенню до конкретного предмету.

Отже, когнітивна соціологія, допомагає визначити цікаву традицію 
теоретичного конструювання поєднання макро та мікро світоглядів аналізу мови, символів та значень. Не дивлячись на те, що цей науковий напрямок не набув загальної інституціоналізації, й не особливо популярний в науковому світі (аніж когнітивна психологія), він має вагоме значення в інтерпретації традиційних поглядів на мову та значення у соціальній взаємодії. На нашу думку - когнітивна соціологія потребує більш глибинного осмислення та грунтовного аналізу, задля розвитку соціальних наук у постмодерному світогляді. Адже на основі проведеного дослідження нами підтверджується основна гіпотеза когнітивної науки, що мисленнєві процеси можна трактувати як процеси оброблення та перетворення ментальних репрезентацій, що є своєрідною традицією аналізу.

Іншим вагомим напрямом аналізу мови виступає - соціолінгвістика, яка вивчає вплив суспільних явищ і процесів на виникнення, розвиток, соціальну й функціональну диференціацію та функціонування мов, а також зворотний вплив мови на соціум.

Об'єктом соціолінгвістики є мова в аспекті соціальної диференціації, а предметом - функціонування мови “в соціальному контексті”, тобто функціонування мови (мов) у структурі соціальних відношень і функцій суспільства.

Соціолінгвістика виникла на теренах мовознавства, соціології, соціальної психології й етнографії у другій половині ХХ ст.

На відміну від нелінгвістичної галузі соціології мови, спрямованої на пояснення соціальних і політичних явищ на підставі мовних фактів, соціологія з'ясовує функціональну природу мови в суспільстві. Потреба виокремлення соціолінгвістики в системі мовознавчих дисциплін була зумовлена не лише внутрішніми чинниками узагальнення й систематизації аспектів зв'язку мови та суспільства, а й зовнішніми чинниками - передовсім процесом деколонізації та створенням численних незалежних держав, яким необхідно було вирішити нагальні питання статусу державної мови, iï унормування та співвідношення з іншими мовами в межах незалежних держав.

Термін “соціолінгвістика" уведений у 1952 р. американським соціологом Х.Каррі. Офіційною датою виникнення цієї галузі вважають 1963 р., у який у США було сформовано Комітет із соціолінгвістики. У 70-ті роки курси з соціолінгвістики офіційно були включені до програм американських університетів.

Предтечею соціолінгвістики був соціологічний напрям у мовознавстві. У ньому мова розглядалася насамперед як засіб спілкування й діяльності людини в соціумі з огляду на суспільний статус і роль особистості; він еклектично поєднував методологічно різнорідні ідеї філософії Просвітництва, психологічного напряму мовознавства, марксистської філософії, філософії позитивізму, однак його завдання чітко були скеровані на соціальну природу мови, ïi комунікативну функцію, відношення мови й суспільства, мови й суспільно заангажованого індивіда.

Представники соціологічного напряму мовознавства (Франція А. Мейє, Ф. Брюно; Швейцарія Ш. Баллі, А. Сеше; Великобрита- 
нія - Дж. Фьорс; США - У. Уітні, Е. Сепір, Б. Уорф; Чехії - В. Матезіус, Й. Вахек; СРСР - Л. Щерба, Л. Якубінський, Є. Поливанов, В. Жирмундський, Б. Ларін, М. Марр, Г. Винокур) досліджували місце й роль мови в суспільстві, функціональне розшарування мови, зв'язок мови й культури, функціонування мови в різних соціальних ситуаціях, зв'язок мови, суспільства й особистості; пояснювали причини мовних змін й еволюцію мов соціальними чинниками, зокрема, диференціацію мов - розселенням народів, уніфікацію - війнами, еволюцію мови ускладненням соціальних відносин, звукові зміни - прагматичними потребами суспільства як зручністю вимови.

Дослідники виокремлюють у сучасній соціолінгвістиці три течії:

1) перша орієнтована на соціологію (досліджує норми мовного вживання, мету вибору варіантів мови, диглосію, білінгвізм, теорію кодів звивино він різних соціальних детермінант),

2) друга спрямована на лінгвістику й вивчає неоднорідність мовної системи з огляду на соціальні параметри, а також зв'язок мовних змін із соціальними умовами;

3) третя має етнографічне і методологічне спрямування [9].

Головними векторами соціолінгвістичних досліджень залишаються проблеми мовної ситуації, мовного колективу, суспільних функцій мови, форм iï існування в соціумі, соціальної диференціації мов залежно від різноманітності соціальних шарів (стратифікаційна) і соціальних ситуацій (ситуативна), двомовності, полі- лінгвізму, мовної міксації, мовної політики, норми, мовного будівництва.

Виділяють такі соціолінгвістичні напрями:

1) макросоціолінгвістики, яка вивчає мовні ситуації у державах, регіонах, групах, аналізує мовні контакти та їхні наслідки, спостерігає мовні конфлікти й мовні зміни залежно від суспільних змін, досліджує соціальну диференціацію національних мов, двомовність, нормалізацію й кодифікацію мови, мовну політику й будівництво;

2) мікросоціолінгвістики, яка зосереджена на індивідуальному мовленні або мовленні мікрогруп, правилах і нормах його реалізації, на набутті комунікативної компетенції та iï ефективному використанні, на відношенні індивідів до мови [10].

Отже, і в контексті розвитку соціолінгвістики ми знову можемо побачити традицію відокремлення макро та мікрорівнів дослідження, без згадування так званого мезорівня. Що підкреслює форму загального наукового теоретизування в сучасному соціологічному дискурсі. Адже в більшості випадків така бінарність викликана природою наукового пізнання, когнітивних методів дослідження, які виходять із традиції об'єктивістських та суб'єктивістських соціально-філософських напрямків. Номіналізм та реалізм будують традицію вивчення мови та значення як форми репрезентації мікро (індивідуального розвитку) та макро (колективного розвитку). На нашу думку, тільки синтез цих двох світоглядів й традицій може призвести до грунтовних змін традиційного аналізу у постмодерному науковому дискурсі. 
Висновки і перспективи подальших досліджень. 1. Когнітивна соціологія та соціолінгвістика є елементами традиційного наукового аналізу мови та значень, смислів, які будуються на основі пізнання макро та мікрорівнів соціальної реальності. 2. Сучасні соціологічні інтерпретації мови в моделях та теоріях комунікаційної взаємодії виходять з ідеологій класичної та некласичної методології дослідження. Основою виступає позитивістський напрям дослідження, що говорить про складність фундаментального відображення комунікації в соціальних системах на глобальному постмодерному рівні - в їх традиційному розумінні. 3. Мова як соціальне явище традиційно пов'язано 3 мультипарадигмальною науковою системою пояснень іiї значень, які інтерпретуються через такі зв'язки в соціальної реальності як: мова та суспільство; мова та особистість; мова та культура; мова та етнос; мова - територіальні та соціальні діалекти; мова та війни; та інші. Що відображає певну “мовну ситуацію” - традицію наукового дослідження іï форм та значень. 4. Вивчення традиційних поглядів на мову та значення дозволяє встановити, що особливо важливою в розумінні даних явищ - постає соціологічна рефлексія, яка дозволяє виокремити синергетичні моделі плюральних інтерпретацій. Що, своєю чергою, обгрунтовує загальні тенденції та традиції подальшого дослідження мови та значень.

Перспектива подальших досліджень визначається у корені традицій соціально-філософського теоретизування, який свідомо створює всі умови для урізноманітнення моделей досліджень макро та мікро рівнів соціальної реальності. Що дозволяє знаходити безкінечні форми інтерпретацій та рефлексій щодо досліджуваного об'єкту та предмету. Важливими для розвитку наукової методології - постають дослідження мови та значень в інформаційному суспільстві в умовах швидкоплинних змін та поширення різноманітних форм масової комунікації, які продукуються інформаційно-комунікативними технологіями. Сучасна традиція має орієнтуватись на футурологічну основу дослідження мовних культурних кодів як в інформаційному просторі комунікації між індивідами, так і у вимірі соціальних взаємодій, викликаних розвитком глобалізації. На нашу думку, науковці дослідники мають прийти до консенсусу (про який зазначав Ю. Габермас у своїй теорії комунікативної дії) використання когнітивної соціології та соціолінгвістики, та реалізувати його у життя - сформувавши нові постмодерні традиції та моделі дослідження соціальної реальності.

\section{СПИСОК ВИКОРИСТАНИХ ДЖЕРЕЛ}

1. Шарков Ф. И. Коммуникология: основы теории коммуникации / Ф. И. Шарков. М.: Дашков и К, 2017. 488 c.

2. McQuail D. Mass Communication Theory: an Introduction / D. McQuail. London: SAGE, 1987. 632 p.

3. Grunig J. Public Relation Theory / J. Grunig. - N.Y., 1998. - P. 29-41.

4. Хабермас Ю. Моральное сознание и коммуникативное действие / Ю. Хабермас. СПб.: Наука, 2001. $380 \mathrm{c}$. 
5. Луман Н. Общество как социальная система / Н. Луман. М.: Логос, 2004. $232 \mathrm{c}$.

6. Коркюф Ф. Новые социологии / Ф. Коркюф; пер. с фр. Е. Д. Вознесенской, М. В. Федоровой; науч. ред. Н. А. Шматко. - М: Ин-т экспериментальной социологии; СПб.: Алетейя, 2002 г. 172 с.

7. Cicourel A.V. Notes on the Integration of Micro- and Macro-Levels of Analysis/ Eds. K. Knorr-Cetina, A. V. Cicourel // Advances in Social Theory and Methodology. Towards an Integration of Micro- and Macro Sociologies. - Boston: Routledge and Kegan Paul, 1981. - P. 53.

8. Подьоло Ж. Социальный порядок: принципы социологического анализа / Ж. Подьоло // Современная западная социология: классические традиции и поиски новой парадигмы. М., 1990. С. 93-110.

9. Вахтин Н. Б. Социолингвистика и социология языка: Учеб. пособие / Н. Б. Вахтин, Е. В. Головко. СПб.: ИЦ “Гуманитарная академия”; Издво Европейского университета в Санкт-Петербурге, 2004. 336 с.

10. Чурилина Л. Н. Актуальные проблемы современной лингвистики: Учеб. пособие / Л. Н. Чурилина. М., 2009. С. 107-135, 307-342.

\section{REFERENCES}

1. Sharkov, F.I. (2017). Kommunikologiya: osnovyi teorii kommunikatsii [Communicology: the basics of communication theory]. Moscow: Dashkov and Co [in Russian].
2. McQuail D. Mass Communication Theory: an Introduction / D. Mc Quail. - London: SAGE, 1987. $632 \mathrm{p}$.

3. Grunig J. Public Relation Theory / J. Grunig. - N.Y., 1998. - P. 29-41.

4. Habermas Yu. (2001). Moralnoe soznanie i kommunikativnoe deystvie [Moral Consciousness and Communicative Action]. SPb.: "Nauka" [in Russian].

5. Luman N. (2004). Obschestvo kak sotsialnaya sistema [Society as a social system]. Moscow: Logos [in Russian].

6. Korkyuf F. (2002) Novyie sotsiologii [New sociology]. St. Petersburg: Aletheia [in Russian].

7. Cicourel A. V. Notes on the Integration of Micro- and Macro-Levels of Analysis/ A. V. Cicourel, Eds. K. Knorr-Cetina // Advances in Social Theory and Methodology. Towards an Integration of Micro- and Macro Sociologies. Boston: Routledge and Kegan Paul, 1981. P. 53.

8. Podolo Zh. (1990) Sotsialnyiy poryadok: printsipyi sotsiologicheskogo analiza [Social order: principles of sociological analysis]. Moscow [in Russian].

9. Vahtin N. B. (2004). Sotsiolingvistika i sotsiologiya yazyika: Uchebnoe posobie [Sociolinguistics and the Sociology of Language: Training manual]. St. Petersburg: IC "Humanitarian Academy" [in Russian].

10. Churilina L. N. (2009) Aktualnyie problemyi sovremennoy lingvistiki: Uchebnoe posobie [Actual problems of modern linguistics: training manual]. Moscow [in Russian]. 